\title{
Inkorporiranje Isusa i njegovih poslanika u tripartitni kanonski okvir (Lk 11,45-53)
}

\author{
Gregory S. Thellman \\ Visoko evanđeosko teološko učilište, Osijek \\ greg.thellman@evtos.hr
}

UDK:27-246

Izvorni znanstveni članak

Primljeno: 3, 2017.

Prihvaćeno: 4, 2017.

\section{Sažetak}

Ova složena kritička egzegetska studija razmatra osobit način na koji Luka u svome evanđelju 11,45-51 koristi Isusove zazive "Jao vama!" protiv pisaraučenjaka. Prepoznaju se četiri elementa Lukine prezentacije, koji doprinose inkorporiranju Isusa i njegovih poslanika u izričito tripartitni kanonski okvir. Dokazuje se da Lukina neobična upotreba grčkog izraza voulxós predstavlja retoričku oznaku kojom se naglašava uloga pisara-učenjaka kao tumača Svetoga pisma i kojom se aludira na Sveto pismo u cijelosti. Povezanost između tri zaziva protiv voulxoí s tripartitnim hebrejskim kanonom nameće se kao daljnji dokaz aluzije na Sveto pismo i tradiciju trostruke objave. Potom se raspravlja o dvama elementima unutar drugog zaziva, objavi "mudrosti Božje” te rasponu mučenika iz prošlosti, pri čemu se ustanovilo da postoje intertekstualne poveznice sa 2. Ljetopisa 24 i 36, što navodi na činjenicu da odabrani ulomak predstavlja tipološku rekapitulaciju prošlih progona i mučeništava, no također i njihovu osudu. U članku se zaključuje da ti posebni elementi pokazuju da Luka tipološki inkorporira Isusa i njegove poslanike unutar tripartitne tradicije objave i kanonskog okvira te da svojim daljnjim implikacijama, Lukino pisano svjedočanstvo (Luka - Djela) progona i ubijanja Isusa i njegovih poslanika potvrduje samostalno predstavljanje toga pisanog svjedočanstva, kao vrhunca u nastavku starozavjetnih tekstova. 


\section{Uvod}

Jedno od glavnih obilježja kako reformacija gleda na Sveto pismo jest njegova narav samopotvrđivanja autentičnosti (Kruger 2012, 89). U skladu s takvim načinom razumijevanja i sve je izrazitija percepcija da su autori novozavjetnih knjiga, osobito autori evanđelja, možda ipak predstavljali svoja djela kao autoritativne spise koji govore o vrhuncu unutar kontinuiteta starozavjetnih knjiga, koje su sami tako dobro poznavali (Smith 2000; Balla 2002, 373; Kruger 2013, 119-54). Sam sadržaj pisanih evanđelja - eshatološko ispunjenje starozavjetnih knjiga i mesijanski autoritet Isusa - nameću jedinstveni autoritativni karakter ovih spisa (Balla 2002, 375). Osim toga, određene tendencije u naraciji i teologiji Evanđelja također upućuju na mogućnost da takvi tekstovi sebe određuju kao integralne dijelove Svetoga pisma (Smith 2000). ${ }^{1}$

Ovaj rad podržava takvo poimanje tvrdnjom da poseban način na koji Luka predstavlja Isusove ukore upućene pisarima-učenjacima u Lukinu evanđelju 11,45-54 postavlja Isusa te "apostole i proroke“ koje on šalje među kanonske proroke te unutar tripartitnoga kanonskog okvira. To upućuje na zaključak da Lukino pisano svjedočanstvo službe i progona Isusa i njegovih poslanika (Luka Djela) zaista predstavlja nastavak kanonskog okvira starozavjetnih knjiga. Pošto je ovaj rad kompozicijska kritika, ograničena je upotreba pojedinih detalja preuzetih iz paralelnih redaka u Mt 23, te izvora ili tradicije koja se obično navodi kao Q. Međutim, fokus ovog eseja nije na Q ili na zajedničkoj tradiciji, već na tome kako Luka koristi svoje izvore da bi postigao svoju sveukupnu narativnu i teološku svrhu.

Četiri elementa koja nalazimo u odabranom tekstu podržavaju tu postavku. Prvo, Lukin neobičan izbor riječi vouıxós za "pisare“ u ovom odlomku služi kako bi se retorički naglasila njihova uloga tumača i učitelja svetih tekstova. Drugo, tri ukora koji se zazivaju na „pisare“ tematski odgovaraju postojećem kanonskom okviru, trima pravcima objave koji su zastupljeni u tradicionalnom hebrejskom kanonu - zakonu, prorocima i mudrosnim spisima, što pak predstavlja aluziju na cjelokupnu biblijsku povijest i objavu.

Treće, autoritet objave „mudrosti Božje“ (Lk 11,49; usp. Mt 23,34) koju citira Isus, ukazuje na vrhunac rekapitulacije povijesti objave službe i progona Isusa i njegovih apostola. Četvrto, Lukino evanđelje 11,51 uspostavlja kanonski niz mučenika od Abela do Zaharije, implicirajući tako da nadolazeći mučenici sljedbenici Isusa, tipološki rekapituliraju biblijsku povijest iako zapravo predstavljaju njezin vrhunac.

1 Istim problemom, ali ovaj put na primjeru Evanđelja po Mateju, bavio sam se u sklopu svoje disertacije (Thellman 2016, 302-9). 


\section{Lukino korištenje izraza vouıxós za „pisare“}

Luka 11,45-54 predstavlja drugi dio veće perikope (11,37-54) koja opisuje događaj pri kojem Isus prisustvuje objedu kod nekog farizeja, gdje su također prisutni drugi farizeji i još jedna skupina za koju se koristi grčki naziv voulxó́. Nakon prvog dijela teksta, $\mathrm{u}$ kojem Isus tri puta zaziva ukor na farizeje (11,37-44), Luka okreće fokus teksta na vouıxoí, drugu skupinu protivnika za koje se ponekad koristi naziv „odvjetnici“, ili „poznavatelji zakona“, ili samo „pisari“ (Bock 1996, 1118). Iako se svih ovih šest ukora može pronaći u tekstu Evanđelja po Mateju, ipak Luka na sasvim poseban način opisuje objed, razlikuje dvije skupine ljudi te koristi riječ vouıxós za skupinu pisara, a ta skupina na neki se način razlikuje od skupine farizeja. Kako bismo ostali dosljedni, od sada pa nadalje za njih ćemo koristiti naziv pisari-učenjaci iz razloga koji će postati jasniji kako budemo napredovali kroz članak.

Zasebno predstavljanje pisara-učenjaka $(11,45)$ izrazito se razlikuje od sinoptičkih paralela koje nalazimo u Matejevu evanđelju, 23. poglavlju, gdje Isus zaziva ukore protiv pisara i farizeja zajedno. Međutim, izraz koji Matej koristi za „pisare“, baš kao i u Markovu evanđelju te većem dijelu Lukina teksta, uobičaje-

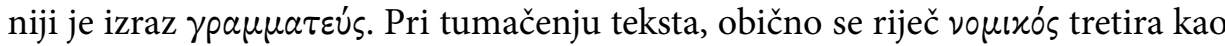

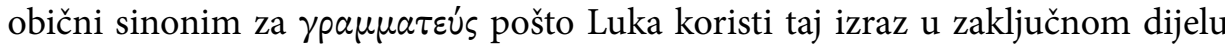
perikope (11,53), očito za istu skupinu ljudi (Marshall 1978, 499; Nolland 1993, 2:666; Bock 1996, 2:1118). ${ }^{2}$ Rijetko se nudi drugačije pojašnjenje zašto Luka ovdje koristi izraz vouıxós $(11,45,46,52)$, posebice kada opisuje istu skupinu koju je

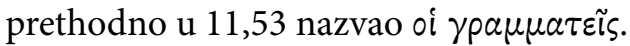

BDAG (675) definira vouıxós prije svega kao pridjev koji se odnosi na nešto što je povezano sa zakonom, a onda i kao na izraz koji se odnosi na osobu „poznavatelja zakona“. U većini slučajeva, kada se izraz koristi u drugom značenju, odnosi se na odvjetnike i pravnike u grčko-rimskom društvu. Riječ je o uobičajenom izrazu u grčkoj literaturi, no rijetko se koristi u vezi sa zakonom - Torom, u židovskom smislu riječi. Postoji samo pet primjera kada se tijekom 1. stoljeća ovaj izraz koristio u židovsko-grčkoj literaturi izvan konteksta kanonskih evanđelja. ${ }^{3} \mathrm{U}$ tri slučaja izraz se koristio za atributne pridjeve, a u jednom slučaju (Tit 3,13 ) odnosio se na odvjetnika, no vjerojatno u grčko-rimskom smislu riječi. Ni

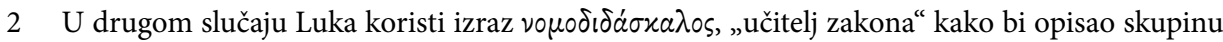
koja je slična farizejima (5,17; usporedi Dj 5,34, gdje se isti izraz koristi za Gamaliela), no ta skupina također se naziva „pisari“ ( put kada se isti izraz koristi drugdje u Novom zavjetu je u 1 Tim 1,7.

3 Tit 3,9, 13; Philo, On the Special Laws, IV.64; Sibylline Oracles, 8.112; i 4 Makabejcima 5,4, o čemu se detaljnije govori u nastavku. 
u jednom slučaju taj izraz ne označava posebnu skupinu židovskih vođa.

No 4. Makabejcima 5,4 predstavlja intrigirajući primjer koji nam može rasvijetliti okolnosti u kojima Luka koristi rečeni izraz. Pisana u dijaspori tijekom 1. stoljeća, ${ }^{4}$ ta knjiga očito podrazumijeva izrazito helenistički kontekst (DeSilva 1998, 11). No Paul Redditt (1993) uvjerljivo tvrdi da vjerno ispunjavanje odredbi židovskoga zakona ( $\nu o ́ \mu o s)$ potiče autora da se brine za svoje čitatelje.

Knjiga je nazvana prema Makabejcima, stoga što autor koristi motiv mučeništva Eleazara i majke sedmorice sinova ( 2 Mak 6,18 - 7,42), da bi zorno naglasio svoju osnovnu postavku. No ono što je najzanimljivije za ovo istraživanje prikazivanje je karaktera Eleazara od strane autora 4. Makabejcima. U 2. Maka-

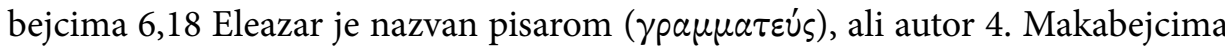
opisuje Eleazara na sljedeći način:

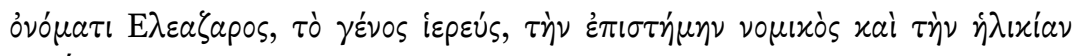
$\pi \rho \eta^{\prime} \alpha \omega \nu$

imenom Eleazar; s obzirom na pretke, svećenik; s obzirom na iskustvo, vješt u poznavanju zakona; s obzirom na dob, stariji ..."

Autor 4. Makabejcima, dakle, preuzima iz 2. Makabejcima izraz „pisar“ ( svećenici, te kao osobu u poodmakloj dobi, no glede njegova znanja i vještina Eleazar je vouıxós. ${ }^{6}$

Ovaj je podatak iz 4. Makabejcima koristan na nekoliko načina. Kao prvo, još jedan židovsko-grčki dokument iz 1. stoljeća potvrđuje opću sinonimiju između

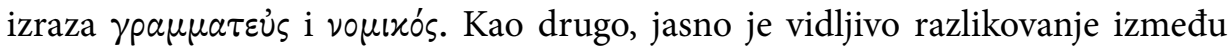
identiteta, koji se nasljeđuje od predaka, i identiteta profesije, pri čemu se izraz vouıxós eksplicitno navodi u vezi s profesijom, a ne kao dio naslijeđa. ${ }^{7}$ Treće, u svjetlu Redditova razumijevanja (1983), retorička prednost izraza vouıxós na

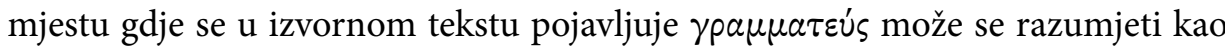
daljnje naglašavanje življenja u skladu sa židovskom Torom.

Osim primjera iz 4. Makabejcima, Lukino eksplicitno korištenje izraza vouıxós za skupinu židovskih pisara jedinstveno je u postojećoj židovsko-grčkoj

4 Izgleda da je postojao konsenzus o datumu iz 1. stoljeća, prema autoru DeSilvi (2006, xiv), no također nameće se jak dokaz bliže vremenske odrednice 20. - 54. g. n. e. (Bickerman 1945).

5 Prijevod autora DeSilve $(2006,15)$. U svojim komentarima, DeSilva jednostavno spominje Eleazara kao „pisara“ bez ikakvih daljnjih objašnjenja.

6 Njegov dvostruki identitet nadalje se potvrđuje u 4. Makabejcima 5,35, gdje se ponavljaju činjenice da je svećenik te da je vješt u poznavanju Zakona.

7 Za uobičajeno preklapanje između predaka svećenika i poziva „pisara“, vidjeti Thellman (2013). 
literaturi, uz moguću iznimku u Matejevu evanđelju 22,35, gdje se izgleda, kao i

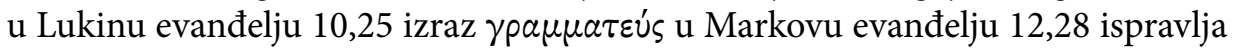
u voulxós (Marshall 1978, 440). ${ }^{8}$ Možemo, dakle, zaključiti da to što Luka preferira korištenje odabranog izraza (šest puta) upućuje na činjenicu da je za to imao posebnu retoričku svrhu.

\section{Pisari i pisari - učenjaci u Lukinim tekstovima}

Kako bismo utvrdili retoričku funkciju riječi vouıxós u Lukinu evanđelju 11,45-53, moglo bi biti korisno prvo razmotriti kako Luka općenito govori o pisarima i pisarima-učenjacima, kao i razvoj njegove priče od Isusove službe u Galileji $(3,23$ - 9,50) preko njegova putovanja $(9,51$ - 19,27) do konačnog dolaska u Jeruzalem $(19,28)$. U navedenim dijelovima teksta, Luka predstavlja Isusove protivnike na vrlo dosljedan način. Glavni protivnici prije dolaska u Jeruzalem su farizeji, koji se posljednji put spominju u 19,39. Prema mišljenju Saldarinija, farizeji kod Luke, puno više nego u drugim sinoptičkim evanđeljima, imaju „važnu društvenu ulogu u Galileji“ te u Isusu vide prijetnju za svoj položaj $(1988,178)$. No, kao što tvrdi Gowler $(1994,236)$, Luka dosljedno drži farizeje na sigurnoj udaljenosti od bilo kakve veze s Isusovom smrću. ${ }^{9}$

Nakon dolaska u Jeruzalem, glavna skupina Isusovih protivnika vodeći su svećenici, koji su nadalje dosljedno povezani s njegovom smrću. Vodeći svećenici pojavljuju se u tekstu samo nakon Isusova dolaska u Jeruzalem, uz jednu iznimku kada Isus najavljuje svoju muku u 9,22. Oni se, dakle, dosljedno vezuju uz Jeruzalem, uz zavjeru o Isusovu ubojstvu, uz Isusovo suđenje i smaknuće. ${ }^{10}$ Nasuprot tomu, pisari su kao dio priče o zavjeri protiv Isusa prisutni od Galileje, tijekom putovanja pa sve do Jeruzalema. No to ne iznenađuje jer biti pisarom ne predstavlja ni nasljednu, ni političku nego profesionalnu karakteristiku, kao što se to jasno navodi u 4. Makabejcima 5,4. Stoga, izrazi koji su se koristili za pisare

8 Međutim, točna je sinoptička odrednica ovdje problematična stoga što postoji usklađenost između Evanđelja po Mateju i Luki u odnosu na Evanđelje po Marku, kao što je primjerice korištenje izraza vouıxós, što izgleda da ukazuje na tradiciju odstupanja od Marka, koja je zajednička tekstovima Mateja i Luke (Davies i Allison 1997, 235-36). Problem je složeniji utoliko što se izraz vouıxós, koji je prisutan u Matejevu evanđelju, ne spominje u nekoliko rukopisa. Ovdje nije moguće detaljno istražiti taj problem, ali tekstualno pitanje dopušta mogućnost da je prisutnost tog izraza kod Mateja posljedica naknadnog ubacivanja na temelju sličnosti s Lukinim tekstom (Schams 1998, 172). Takav scenarij bio bi u skladu s radom svakog pojedinog autora i značio bi da je eksplicitno korištenje izraza voulxós za židovske pisare pojava koja se isključivo pojavljuje u Lukinim tekstovima.

9 Na sličan način, Saldarini $(1988,179)$ opisuje farizeje u Lukinu evanđelju kao one koji nisu ni prijateljski, ali ni neprijateljski nastrojeni.

10 Starješine su redovno povezani s vodećim svećenicima, no to je manje naglašeno kod Luke nego kod Mateja i Marka. 
mogli su prelaziti preko kulturnih i društvenih granica (Thellman 2013).

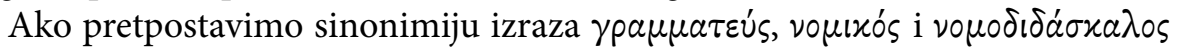
kod Luke, možemo uočiti da on u svome evanđelju 21 put koristi neki od naziva

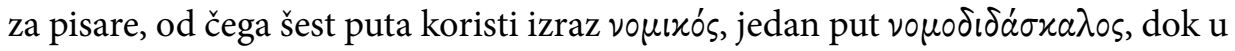

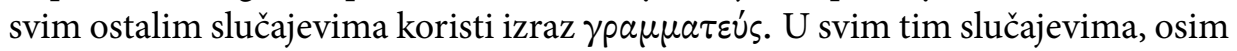
$\mathrm{u}$ šest slučajeva, pisari se povezuju s nekom drugom navedenom skupinom, kao već dio grupe Isusovih protivnika. U tekstu Evanđelja po Luki od 5,17 do 15,2 osam puta ih se povezuje $s$ farizejima i sedam puta s vrhovnim svećenstvom, od toga šest puta od 19,4 do 23,10 i jedan put u 9,22, gdje Isus najavljuje svoju muku.

Tamo gdje su pisari eksplicitno povezani s nekom drugom skupinom, primjerice strankom farizeja, ili s vrhovnim svećenstvom u Jeruzalemu, izgleda da preuzimaju ulogu i svrhu navedene skupine, što navodi na pomisao da su pisari bili uključeni u svaku skupinu, unutar koje su predstavljali zasebnu podskupinu učenih ljudi. ${ }^{11}$ Tako u epizodi u kojoj su pisari poistovjećeni s farizejima, tema je rasprave obredna čistoća $(5,30 ; 15,2)$ ili problem što Isus iscjeljuje subotom $(6,7 ; 14,3)$. Nadalje, tu su i Lukini komentari o odbacivanju Ivanova krštenja $(7,30)$ i neprijateljstva prema Isusu $(11,53) .{ }^{12}$ Još jedna koalicija između farizeja i pisara opisana je u 5,17-26, gdje se dovodi u pitanje Isusov autoritet za praštanje grijeha. No taj odlomak donekle prkosi jednostavnoj kategorizaciji pošto Lukino evanđelje 5,17 podrazumijeva jedino mjesto u tekstu gdje se

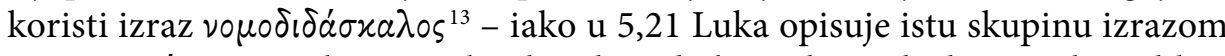

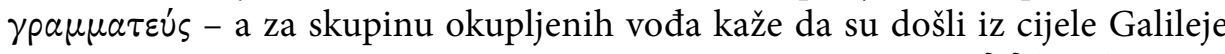
te iz Judeje i Jeruzalema. Izgleda da su učitelji zakona ( oni koji su došli iz Jeruzalema budući da Luka farizeje ne povezuje s Jeruzalemom.

To može poslužiti kao važna poveznica između pisara, koji su povezani s farizejima u Galileji, i pisara koji su povezani s vrhovnim svećenstvom u Jeruzalemu. Pitanje Isusova autoriteta istaknuto je u ovoj perikopi, kao i u 20,1-19, gdje vrhovni svećenici i pisari provociraju Isusa. U svim drugim slučajevima, koalicija između vrhovnih svećenika i pisara dovodi se u vezu sa zavjerom protiv Isusa, suđenjem i njegovom smrću $(19,47 ; 22,2 ; 22,66 ; 23,10)$. Sve u svemu, kada se pisari kao skupina povezuju s nekom drugom istaknutom skupinom Isusovih protivnika, kao što su farizeji ili vrhovni svećenici, oni u osnovi preuzimaju karakter

11 Ova se vrsta pripadnosti eksplicitno navodi u Lukinu evanđelju 5,30, gdje Luka spominje farizeje i „njihove pisare“.

12 Pošto se razmatra ovaj dio perikope, autor će se u nastavku time detaljnije pozabaviti.

13 On tu riječ koristi u Dj 5,34 za Gamaliela, koji je također farizej i član Sanhedrina. 
te skupine. ${ }^{14}$ Moguća poveznica između dviju skupina pisara jest pitanje Isusova autoriteta, no moguće je da je to pitanje više zanimalo jeruzalemske pisare, koji su zajedno s bliskim vrhovnim svećenicima vidjeli Isusov autoritet kao prijetnju svome društvenom položaju.

No u dva odlomka, u kojima su farizeji specifično povezani s pisarima-učenjacima ( $\nu \circ \mu(x \circ i)$, tumačenje i primjena teksta dobivaju značajnu ulogu $(7,27-30$; 14,1-6). U prvome slučaju, farizeji i pisari-učenjaci odbacuju Ivanovo krštenje jer nisu uspjeli razumjeti Ivanov eshatološki identitet u svjetlu retka Malahije 3,1 koji Isus ranije citira. U drugome slučaju, Isus izaziva skupinu farizeja i pisara razmatranjem zakonitosti iscjeljivanja u subotu, aludirajući na dva teksta iz Tore (Pnz 22,4 i Izl 23,5).

Tumačenje Svetog pisma tema je na još tri druga mjesta, osim u Lukinu evanđelju 11,45-52, gdje izgleda da pisari nisu povezani s nekom drugom skupinom. $\mathrm{Na}$ jednome mjestu spominje se razgovor između određenog pisara-učenjaka (voulxós) i samog Isusa na temu najvažnije zapovijedi $(10,25)$. Za Isusa, to je u neposrednoj vezi sa židovskom Torom (vónos), dok pisar-učenjak, kojeg Isus potiče da odgovori na pitanje, citira iz knjige Ponovljenog zakona.

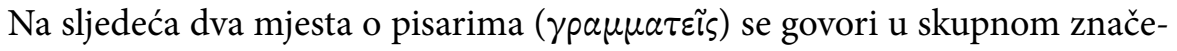
nju $(20,39 ; 20,46)$. U prethodnom slučaju izgleda kao da pisari podržavaju Isusovo korištenje Izlaska 3,2-6, kada odgovara saducejima na njihov izazov vezan uz prijepor na temu uskrsnuća. ${ }^{15} \mathrm{U}$ kasnijem slučaju, Isus dovodi u pitanje način na koji pisari tumače citirani mesijanski tekst (Ps 110,1), a kasnije iznosi oštru kritiku protiv njihova licemjerja i arogancije. Tako, u sva tri slučaja, kada se o pisarima govori a da ih se ne povezuje s nekom drugom skupinom, te u dva slučaja kada su pisari-učenjaci ( $\nu$ ouıxoí) povezani s farizejima, razgovor s Isusom usredotočen je na pravilno tumačenje i primjenu Pisma te podrazumijeva eksplicitne navode i aluzije na Pismo. ${ }^{16}$ Sve to upućuje na činjenicu da je za Luku, bez obzira na to kako se definiraju židovski pisari, njihova prvenstvena uloga poznavanje, tumačenje i poučavanje Pisma (Thellman 2013). ${ }^{17}$ To također sugerira da, kada su pisari u tekstu gdje je tumačenje i primjena Pisma od velike važnosti stavljeni

14 To se slaže sa Saldarinijevim $(1988,273)$ zaključkom da pisari nisu činili ,jedinstvenu skupinu ili organizaciju“. No različite skupine pisara mogle su biti povezane s različitim društvenim skupinama ili organizacijama.

15 To pitanje upućuje na činjenicu da su ti pisari u nekoj vezi sa strankom farizeja.

16 Više o ovoj temi, ali i općenito o pisarima u evanđeljima, vidjeti Thellman (2013).

17 Isto se može reći za druge sinoptičke evanđeliste, kao i za Ben Siru $(38,24-39,11)$. Schams (1998, 15-35) daje kritički no koristan sažetak povijesti razmišljanja o ovome pitanju od Schürera naovamo. Iako Schams smatra da je većina učenjaka koji slijede Schürerovo poimanje pisara u krivu, njezin je zaključak da su pisari prije svega bili pisci, ali istovremeno dopušta da su „neki pisari bili poznati kao ... stručni tumači Pisma i zakona“ (327). 
u vezu s farizejima, tada Luka koristi izraz voulxós.

\section{Pisari-učenjaci (Noulxoí) u Lukinu evanđelju 11,45-53}

U prethodnom pregledu načina koje Luka koristi da bi govorio o pisarima i

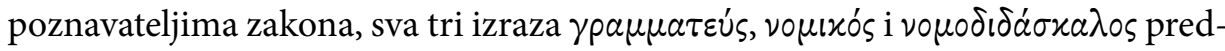
stavljaju osnovne sinonime korištene u redcima gdje očito oba termina koristi za istu skupinu ljudi $(5,17$ i 5,21; 11,45-52 i 11,53). No to što ćemo jednostavno potvrditi sinonimnost tih izraza ne rješava problem zašto je Luka u 11,45-52 upotrijebio izraz koji se inače tako rijetko koristio (vopixós). ${ }^{18}$

Saldarini sugerira da Luka koristi voulxós zato što su „u autorovu svijetu odvjetnici, a ne pisari, funkcionirali kao stručnjaci od autoriteta u sferi društvenih i religijskih zakona i običaja" (183). Iako to može biti samo djelomično točno, Saldarini je prije bio skeptičan na pomisao da je Luka koristio rečeni izraz kao „pomoć svojim poganskim čitateljima" $(1988,183$; cf. Schams 1998, 171). Kad bi to bio Lukin razlog, očekivalo bi se od njega da u oba svoja teksta koristi samo izraz

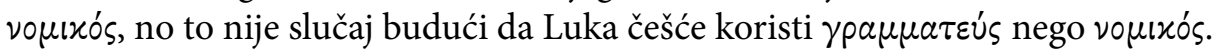

Druga je mogućnost da scena objeda ovdje i u drugim Lukinim tekstovima slijedi literarnu tradiciju helenističkog simpozija (Steele 1984, 379; Smith 1987, 613). U tome bi slučaju izraz voulxós mogao biti prirodan izbor i bolje bi predstavljao počasne goste višega društvenog statusa (Steele 1984, 381). Ovaj je argument podržan korištenjem izraza vouıxós u Lukinu evanđelju 14,3 u jednoj od tri scene, za koje se smatra da predstavljaju primjere simpozijskog žanra (Steele $1984,184)$. No ta mogućnost ne daje objašnjenje za korištenje voulxós u 7,30 i 10,25. Riječ je, naime, o dvama odjeljcima koja nemaju baš nikakvu vezu s helenističkim kontekstom odlomka, ali koji se, kao što je prethodno rečeno, više bave izrazito židovskim pitanjima, a posebice tumačenjem Pisma. Nadalje, u drugoj sceni simpozija 7,36-50 Luka uopće ne uključuje pisare.

Posljednja je mogućnost da Luka koristi voulxós kako bi naglasio da su pisari tumači i učitelji Tore, u svrhu izrazitijeg aludiranja na tradiciju trostruke objave uz pomoć triju zaziva (vidjeti u nastavku). Već je prije pokazano da svaki put kada se izraz pisari pojavi samostalno, tema o kojoj se govori redovito je povezana s pitanjima tumačenja Pisma i prisutni su citati, a kada se pisari spominju zajedno s farizejima i tumačenje Pisma zauzme središnju ulogu, tada Luka daje prednost korištenju izraza voulxós $(7,30)$. U ovome su odlomku govori samostlno o pisarima ili pisarima-učenjacima, $\mathrm{i} u$ isto vrijeme povezano $\mathrm{s}$ farizejima.

Sve ovo upućuje na to da Luka koristi vouıxós kao retorički alat kojim se in-

18 Većina komentatora jednostavno naziva te riječi sinonimi i ne ulazi u razloge zašto se koristi jedna ili druga riječ. 
tenzivira povezanost pisara s tumačenjem Tore. ${ }^{19}$ Pridjevno značenje „vješt u poznavanju zakona" i zajednički korijen riječi s imenicom vopós možda je za Luku bio djelotvoran način da potakne svoje čitatelje da neposrednije razmišljaju o ovoj središnjoj ulozi koju su tada imali pisari. ${ }^{20}$

\section{Tri zaziva protiv pisara-učenjaka}

Lukino evanđelje 11,45-53 je kao što je već naprijed bilo rečeno, izniman tekst u smislu kako Luka je predstavljao pisare. Drugdje su oni obično združeni s drugim skupinama (farizejima ili vrhovnim svećenicima) kao Isusovi protivnici ili se na nekoliko mjesta o njima govori samostalno. No ovdje su pisari-učenjaci jasno povezani s farizejima iako se ipak razlikuju od njih. U Lukinu tekstu spominje se šest zaziva, od kojih su prva tri usmjerena protiv farizeja (11,42-44), a druga tri protiv pisara-učenjaka $(11,45-53){ }^{21}$

Isus ne osuđuje farizeje zbog njihova tumačenja Tore, već zbog licemjerja $\mathrm{i}$ arogancije u držanju svoje halakah, koja zapravo predstavlja način njihova života (Sanders 103). No pisari-učenjaci također bivaju uvrijeđeni Isusovom osudom $(11,45)$, možda zato što je farizejska halakah o kojoj se ovdje raspravlja barem djelomično izgrađena na njihovu tumačenju Pisma. Primjedba pisara-učenjaka u 11,45 je intrigantna zbog toga što povezuje dvije skupine, dok u isto vrijeme razjašnjava da pisari-učenjaci smatraju za sebe da su posebni.

Narav triju zaziva protiv pisara-učenjaka jasno se razlikuje od zaziva upućenih farizejima. Isus je kritizirao farizeje zbog njihova licemjerja $(11,42)$ i taštine $(11,43)$ te zbog mogućega negativnog utjecaja njihova ponašanja na ljude $(11,44)$.

19 Za slično viđenje ovoga problema, vidjeti Sanders $(1987,104)$.

20 Također, sasvim je moguće, iako manjak dokaza umanjuje vrijednost argumenta, da izraz

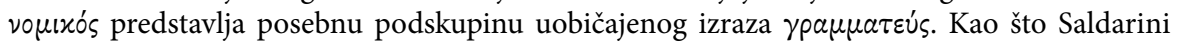
$(1988,273)$ tvrdi, „pisari su možda povremeno imali udruženja za koja mi danas ne znamo.“ U tome bi slučaju izraz vouıxos, na temelju njegova korištenja u Lukinu evanđelju, mogao biti izraz koji je označavao višu kategoriju pisara.

21 Zapravo, ukupno je sedam ukora, ali prvi protiv farizeja (39-41) ne počinje s „Jao vama!“ Tako Luka simetrično uokviruje veći odlomak s po tri zaziva upućenih svakoj pojedinoj skupini. Paralelne retke nalazimo u Matejevu evanđelju 23 (4, 13, 29-36), ali raspored i vokabular su kod svakog autora donekle drugačiji. U Mateju Isus se obraća zajedno pisarima i farizejima u jednome zazivu. Bock (2:1107) tvrdi da su paralelni redci u Mateju „konceptualne, a ne verbalne naravi“ tako da ova perikopa odražava neovisnu tradiciju na kojoj je utemeljeno Matejevo evanđelje, 23. redak. Iako je Bock ovdje u manjini, ipak uspijeva barem dovesti u pitanje postavku da se te priče oslanjaju na isti izvor ili tradiciju. Isus je možda doista na sličan način dao ukor, ali u različitim okolnostima. No takvo viđenje ne uvjetuje određenu strukturu naracije i vokabular koji koristi Luka. 
Pisari-učenjaci se s druge strane osuđuju specifično zbog lošeg vođenja naroda, posebice s obzirom na njihovo učenje. U prvome slučaju $(11,46)$ oni opterećuju narod teretom koji je teško nositi, a sami taj teret ne nose. Teret se ovdje vjerojatno odnosi na njihovo tumačenje i primjenu Mojsijeva zakona (Fitzmeyer 1985, 945), koji je čak i njima bilo teško vršiti u cijelosti (Green, 1997, 474). ${ }^{22}$

$\mathrm{U}$ drugom zazivu $(11,47-51)$ Isus povezuje njihove zgrade s grobovima proroka i činjenicom da su njihovi preci ubijali proroke. ${ }^{23}$ Tako implicira da pisariučenjaci nastavljaju tradiciju svojih predaka tako što namjerno prešućuju riječi proročanstava. Taj je ukor za Isusa najvažniji i ima ključnu ulogu u ovoj raspravi te će se detaljnije razmatrati u dva sljedeća odlomka. Konačno, pisari-učenjaci bivaju ukoreni zbog toga što odbacuju istinsko znanje $(11,52)$ i tako drugima priječe pristup tome znanju. U svakom slučaju, Isus kori pisare-učenjake zbog toga što su propustili pravilno poučavati narod, ljude su opteretili uputama iz Tore a pritom prešutjeli riječi proročanstva, onemogućavajući tako istinsko znanje.

Fitzmeyer povezuje ova tri zaziva protiv pisara-učenjaka s tri dijela tradicionalnoga židovskog kanona: zakon, proroci i mudrosti $(1985,945)$. Postoje velike razlike u razmišljanju o razmjeru, rasporedu te otvorenoj ili zatvorenoj naravi kanona židovskih spisa u Isusovo vrijeme (McDonald i Sanders 2002, 4). Upravo na temelju tekstualnog materijala iz redaka koje mi ovdje raspravljamo, neki tvrde da je već u 1. stoljeću postojao tripartitni kanon (Beckwith, 1984), dok su drugi mišljenja da u to vrijeme nisu postojala takva kanonska ograničenja (Sundberg 1964). ${ }^{24}$

No Steven Chapman (2000) i Christopher Seitz (2009) priklanjaju se finije iznijansiranom pristupu koji uzima u obzir funkcioniranje tripartitne „gramatike" ili okvira koji se primjenjivao u novozavjetno vrijeme (vidjeti također Dempster 1997), čak i ako kanon tada još nije bio „službeno“ zaključan. To je u skladu s dokazima koje nalazimo na nekoliko mjesta u Novome zavjetu, gdje se fraza „zakon i proroci“ očito odnosi na funkcionalnu skupinu svetih spisa. ${ }^{25}$ Izgleda da je Luki poznata ova trostruka podjela $(24,14)$ jer navodi da Isus spominje „Mojsijev zakon, proroke i psalme“. Raniji dokaz iz prologa tekstova Bena Sirina odnosi

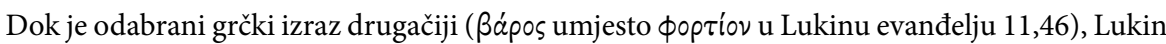
sažetak odluke Sabora u Jeruzalemu o kršćanima poganima i zakonu u Djelima 15,28 također govori o konceptu po kome se držanje zakonskih odrednica smatra teretom.

23 Neki komentatori (Marshall 1978, 500) primjećuju da, pošto publika koja sluša ove ukore nije definirana, može se pretpostaviti kako su te riječi namijenjene većoj skupini ljudi nego što su to pisari-učenjaci. No ta tvrdnja ipak je upitna zbog jasne simetrije cijeloga tekstualnog odjeljka (Nolland, 1993, 667).

24 Nije posve sigurno može li se glavni rabinski dokaz tradicionalnog rasporeda hebrejskog kanona (b. B. Bat. 14b) prenijeti natrag u 1. stoljeće. 
se na „zakon, proroke i druge knjige“. ${ }^{26}$ Dokaz o kojem govore Chapman i Seitz ukazuje na postojanje tripartitnog okvira koji je vrijedio u vrijeme Isusa i Luke, a Luka ga je zasigurno bio svjestan.

Nadalje, sam Stari zavjet ukazuje na odrednice tripartitne tradicije objave, čak i ako još ne postoji tripartitni kanon pisanih svetih spisa. Jeremija $(18,18)$ i Ezekiel $(7,26)$ predstavnici su tradicija objave i osobe koje su blisko povezane s tim tradicijama (Dempster 2008). Kako kod Jeremije, tako i kod Ezekiela, Tora ili nauk povezana je s ulogom svećenika (vidjeti također o Eleazaru u 4. Makabejcima). Zanimljivo je da Hayward u svome tumačenju targumskih komentara na ove i druge tekstove iz korpusa proročkih spisa, zaključuje da „Targum koji komentira tekstove kasnijih proroka poima pisare kao poznavatelje Tore. Oni su povezani sa svećenicima utoliko što se bave Zakonom te su, kao i svećenici, uključeni u proročku kritiku društva i u odgovarajuće javne rasprave na tu temu" (Hayward 1985, 217). To je u skladu s time da Luka govori o pisarima kao tumačima Tore i povezuje ih sa svećenicima u Jeruzalemu.

Jeremija također povezuje „riječ"s prorokom i savjetom mudra čovjeka. $\mathrm{Na}$ sličan način, Ezekiel povezuje „viziju“ s prorokom i savjetom starijeg čovjeka. Ta dva starozavjetna retka još više upućuju na mogućnost da je već tada, u vrijeme osvajanja i progona, postojala trostruka tradicija objave. Kako su se postupno prikupljali pisani dokumenti povezani sa spomenutim tradicijama, koji su se također koristili u bogoslužju, vjerojatno se o njima počelo razmišljati na taj tripartitni način pa ih se sukladno tomu grupiralo po kategorijama te su postupno dobivali tripartitni oblik kasnije židovske Biblije. Za ovaj rad nije neophodno pretpostaviti da se u Isusovo vrijeme koristio zaključani kanon, no ipak izgleda da je u to vrijeme postojao barem okvir za tripartitnu objavu ili kanon, što se može razumjeti kao pozadina triju skupina ukora protiv pisara-učenjaka (

Luka u ovoj perikopi nije samo koristio voulxós kako bi opisao identitet pisara-učenjaka kao službenih tumača svetih spisa i retorički naglasio aluziju na njih u cijelosti, već svojom aluzijom trostruke strukture odlomka dodatno učvršćuje i potvrđuje tradiciju trostruke objave i tripartitni kanonski okvir.

26 Kao što je vidljivo u tim izvorima, treći dio, koji se obično u rabinskoj tradiciji naziva „spisi“, manje je definiran nego što je to slučaj sa „zakonom i prorocima“ iako mudrosni spisi ovdje zasigurno predstavljaju ključni element. Smatra se da izraz „druge knjige“ kod Bena Sire označava rastući, neograničeni broj svetih spisa. No čak i ako je to tako, „zakon“ $i$ „proroci“ tako se proširuju, pri čemu „druge knjige“ predstavljaju treću skupinu tekstova koji se vezuju uz Bena Siru, a podrazumijevaju „pouke i mudrost“. 


\section{Objava "mudrosti Božje”}

U drugom zazivu protiv pisara-učenjaka, Isus ih kori zbog toga što „grade grobove proroka" koje su njihovi očevi pobili. Izgleda da Isus ovdje govori o tome kako pisari-učenjaci, koji su tumači Tore i svetih spisa, gradeći grobove, zapravo potvrđuju djela svojih predaka. Pokapanjem proroka, njihova poruka zapravo se simbolički pozicionira u daleku prošlost i proroci su tako ušutkani od strane pisara-učenjaka. Kao što tvrdi Marshall, Isus je tako optužio sadašnju generaciju narodnih vođa da oponašaju svoje pretke tako što odbijaju slušati proroke (Marshall 1978, 501).

To zaključuje sljedeću Isusovu tvrdnju da je „mudrost Božja rekla 'Poslat ću im proroke i apostole“. Ponuđen je niz prijedloga tumačenja izraza „mudrost Božja“. Bilo je sugestija kako se odnosi na izgubljenu apokrifnu knjigu pod naslovom „Mudrost Božja“, no za to nije bilo dokaza (Marshall 1978, 502-3). Drugi su pretpostavljali da se radi o proročanstvu rane Crkve, za koje se smatralo da dolazi s uskrslim Isusom, stoga se učitava na Isusovim usnama i prije uskrsnuća kao dio ishodišne tradicije (Ellis 1963). No to je sve previše spekulativno i kreće od pretpostavke da Lukin tekst i ishodišna tradicija nisu povijesno utemeljeni. Nadalje, nema čvrstog dokaza da su se takva postuskrsna proročanstva uopće koristila u Crkvi na takav način.

Marshall zaključuje da se možda radi o Isusovu posebnom načinu korištenja židovske tradicije, koje odmah potom preuzima rana Crkva, izražavajući ga svojim riječima (1978, 502-3). Za svaki od ovih prijedloga postoji premalo dokaza da bi ih se dalje razvijalo, a prisutna je i svojevrsna nesklonost da se ipsissima vox ovog odlomka pripiše Isusu. Paralelni tekst u Matejevu evanđelju navodi da je Isus ove riječi izgovorio u prvom licu te eksplicitno ukazuje na to da Isus govori kao mudrost Božja. No razvijenija mudrosna kristologija kod Mateja može ukazivati na uređivanje izvornog teksta (Suggs 1970, 59-60) iako, kao što ću pokazati u nastavku, uredničke intervencije Luke i Mateja nisu baš toliko različite, kao što bi se činilo na prvi pogled.

Dale Allison (2000, 149-52) sugerira da se pozadina temeljne Q tradicije (Lk 11,49-51; Mt 23,34-36) nalazi u 2. Ljetopisa 24,19-27. Allison posebice smatra da

\begin{tabular}{|c|c|c|c|}
\hline LXX 2 Ljet 24,19 & LXX 2 Ljet 36,15-16 & Mt 23,34 & Lk 11,49 \\
\hline 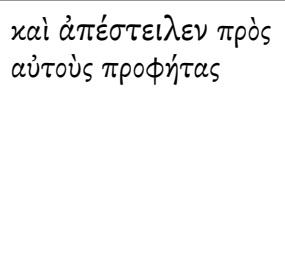 & 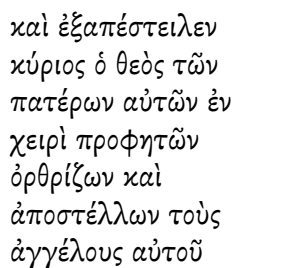 & 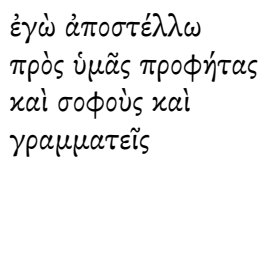 & 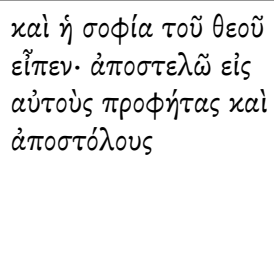 \\
\hline
\end{tabular}


je vokabular u 2. Ljetopisa 24,19 vrlo blizak tekstovima Luke i Mateja, u kojima se govori o poslanju, iako se sličnosti mogu također uočiti u 2. Ljetopisa 36,15-16.

Usporedba ovih tekstova otkriva, međutim, ključnu razliku u glagolskim vremenima za glagol $\dot{a} \pi \circ \sigma \tau \dot{\varepsilon} \lambda \lambda \omega$. Ljetopiščevo korištenje prošlog vremena pokazuje da razmatra povijesni obrazac otpadništva, slanja proroka te odbacivanja tih proroka i Božje osude. ${ }^{27}$ No Matej koristi sadašnje vrijeme te, zajedno s činjenicom da Isus koristi te riječi u prvome licu, naglašava Isusovo rekapituliranje spomenutog obrasca, tako što o njemu govori u sadašnjem vremenu. ${ }^{28}$ Kod Luke, Isus spominje govor mudrosti Božje ( $\varepsilon i \pi \varepsilon v)$ u prošlom vremenu, no unutar samoga govora izraz ả $0 \circ \tau \tau \dot{\varepsilon} \lambda \lambda \omega$ u budućem je vremenu $(\dot{\alpha} \pi \circ \sigma \tau \varepsilon \lambda \tilde{\omega})$.

Kod Mateja i Luke je, dakle, obrazac poslanja - otpadništva - osude iz kanonske prošlosti obnovljen na način da obuhvaća sadašnjost i budućnost. Takva kanonska rekapitulacija potvrđuje se u Isusovoj tvrdnji da će sadašnji naraštaj biti odgovoran za krv svih proroka (Lk 11,50; Mt 23,35). Tako se „povijesni jezik Ljetopisa“ premjestio u „eshatološko Isusovo vrijeme“ (Allison 2000, 149).

Također, na temelju Baruha 3,36-4,1 Allison predlaže da se mudrost identificira s Torom, a pošto se Tora također često predstavlja kao cjelokupno Sveto pismo, "'mudrost Božja' predstavlja način da se govori o Bibliji“" u cjelini (2000, 152). Čak i ako je ovaj drugi dio njegova prijedloga nešto manje uvjerljiv - uz pretpostavku da je temeljna tradicija ili sam Luka napravio istu poveznicu koju nalazimo u Baruhu ${ }^{29}$ - Allisonovo razumijevanje odabranog teksta kao eshatološke rekapitulacije biblijske povijesti, koja se sada nastavlja kroz službu Isusa i njegovih poslanika, doista je uvjerljiva. No, kao što je prethodno pokazano, obnavljanje obrasca iz Ljetopisa sugerira da se govor „mudrosti Božje“, koji je u Ljetopisima smješten u prošlo vrijeme i povezan sa Svetim pismom, sada ostvaruje kao vrhunac u sadašnjosti i neposrednoj budućnosti narativnog svijeta Lukinih tekstova (Luka - Djela).

Kroz dvije novozavjetne Lukine knjige, proročko poslanje (å $\pi \circ \sigma \tau \dot{\varepsilon} \lambda \lambda \omega)$ nameće se kao važna tema. Nakon božanskog poslanja anđela na početku Evanđelja $(1,19,26)$, Ivan $(7,27)$ je poslan kao Božji proročki poslanik da pripravi put za Isusa, a Isus je pak prikazan kao poslan od Boga da ispuni izraelska eshatološka obećanja (Lk 4,18, 43; Dj 7,37) i proročki pozove Izrael na pokajanje (Dj 3,26), nakon čega je odbačen i smaknut (Dj 7,52). No Isus također funkcionira kao poslanik koji ima božanski autoritet, kako tijekom svoje službe na Zemlji (Lk

27 Isti je obrazac prisutan u širem smislu u cjelokupnoj povijesti Ponovljenog zakona.

28 Matejevi proroci, mudraci i pismoznanci mogu se također uklopiti u okvir tripartitne objave.

29 Moglo bi se tvrditi da u svjetlu Ljetopisa „mudrost Božja“ jednostavno predstavlja način referiranja na povijesne tekstove Ljetopisa, kao na donekle dvosmisleni treći dio kanonskog okvira objave. 
9,1-6; 10,1-20; 22,35), tako i nakon uskrsnuća (Dj 1,8; 9,17; 26,17). ${ }^{30}$ Proroci i apostoli se drugdje potvrđuju kao nositelji dviju glavnih vodećih uloga u ranom kršćanskom pokretu (Dj 1,2; 11,27; 13,1; 15,32; 1 Kor 12,28-29; Ef 2,20; 3,5; 4,11; Otk 18,20).

Isus, kojega Luka na više mjesta prije ovih redaka opisuje kao punog Božje mudrosti (Lk 2,40, 52; 11,31), dakle je oboje: poslanik, ali ujedno i onaj kroz kojega se Božje poslanje ostvaruje. U tome smislu, Isusovo spominjanje Božje mudrosti u 11,49 odražava ne samo povijesni govor objave Svetog pisma, koje se ostvaruje u sadašnjosti, već se u kontekstu vrhunca rekapitulacije implicira da Isus u okviru Lukine priče u sebi samome aktualizira govor objave mudrosti Božje, uzimajući u obzir sadašnju i buduću službu apostola koja se opisuje u evanđeljima i Djelima. Izraz „mudrost Božja “ u Lukinu evanđelju, dakle, funkcionira kao referenca na povijesne svete spise, a tipološki se aktualizira kroz objavu autoriteta Isusove osobe, stoga Matejevi i Lukini zapisi nisu baš toliko konceptualno različiti koliko bi se to isprva moglo činiti. Ova dvostruka uloga poslanika i onoga koji šalje također potvrđuje usporedni karakter odnosa između Isusove službe u Evanđelju po Luki i službe koju su imali apostoli poslani od Isusa u Djelima. ${ }^{31}$

\section{Zaharijin identitet i „kanonski“ raspon mučenika}

Ranije spomenuti vrhunac rekapitulacije, koji jasno ukazuje na Isusovo božansko poslanje te slanje proroka i apostola, odgovara rekapitulaciji čiji je vrhunac božanska osuda tadašnje generacije vođa koji su odbacili Isusa i loše obavili svoju ulogu tumača i učitelja Tore. Isus objavljuje da će trenutačna generacija biti odgovorna za krv svih proroka. Nadalje te proroke određuje rasponom od Abela do Zaharije.

Iako Abel nije bio prorok, njegova smrt od Kainove ruke se u 4. Makabejcima 18,10-11 navodi kao prvo kanonsko mučeništvo (usporediti s 1 En 22,7). ${ }^{32}$ No identitet Zaharije u Lukinu evanđelju 11,51 i Matejevu 23,35 donekle je za tumače Biblije predstavljao veći problem. Dio je problema nastao uslijed Matejeve identifikacije Zaharije kao Berekjinog sina. No Berekjin sin, prorok koji je povezan s knjigom proroka Zaharije $(1,1)$ nije poznat kao mučenik i ne postoji poznata tradicija njegova mučeništva (Davies i Allison 1997, 318). Iako Luka izo-

30 U vezi s tim, uskrsli Isus obećava da će poslati ( $\dot{\varepsilon} \gamma \omega \dot{\alpha} \pi \circ \sigma \tau \varepsilon \lambda \lambda \omega)$ obećanog Duha kako bi apostole osposobio za službu, Lukino evanđelje 24,49.

31 Paralelizam između Luke i Djela puno je puta dokazan od strane mnogih tumača novozavjetnih tekstova. Vidi primjerice u Denova (1997).

32 Zanimljivo je da ovo spominjanje kanonskih mučenika slijedi odmah nakon spominjanja učenja koji proizlaze iz zakona i proroka $(18,10)$. 
stavlja navesti ime oca, Zaharijin identitet nije znatno jasniji u trećem evanđelju. Za ovaj problem ponuđena su tri druga objašnjenja. Neki crkveni oci sugeriraju da je taj Zaharija bio svećenik i otac Ivana Krstitelja. Ali još uvijek nema dokaza o njegovu mučeništvu i teško je uvidjeti zašto bi se njega navodilo kao vrhunac popisa mučenika kada je Isus njegova sina mučenika (Lk 9,7-9) već nazvao najvećim prorokom.

Druge su dvije mogućnosti tumačenja, koje su ponuđene od suvremenih tumača Biblije, da je Zaharija sin Jojade iz 2. Ljetopisa 24,20 ili pak sin Bareje, čiju mučeničku smrt blizu hrama od ruke zelota 69. g. n. e. bilježi Josip Flavije. ${ }^{33}$ Ovaj je drugi prijedlog identiteta vrlo problematičan iz nekoliko razloga (Chapman 1912), ali uglavnom zato što taj Zaharija nije bio ni prorok, ni kršćanin, niti je ubijen od strane službenog vodstva, već od strane zelota. ${ }^{34}$ Nadalje, mjesto ubojstva nameće činjenicu da je Zaharija morao biti svećenik (Davies i Allison 1997, 318).

Većina tumača stoga smatra da je Zaharija Jojadin sin iz 2. Ljetopisa 24,1522. Taj je Zaharija bio svećenik, ali obavljao je također i ulogu proroka, pozivajući judejskog kralja i knezove na pokajanje te je zato bio ubijen u hramu. Nadalje, već sam ranije pokazao da knjiga 2. Ljetopisa 24. poglavlje pruža odgovarajuću pozadinu za retke u kojima se spominje poslanje od strane „mudrosti Božje“. Identificiranje Zaharije iz Lukina evanđelja 11,51 kao Jojadina sina iz 2. Ljetopisa 24,20 dodatno potvrđuje i učvršćuje ovu intertekstualnu poveznicu.

Značenje raspona mučenika od Abela do Zaharije izaziva puno više neslaganja. Mnogi tumači zaključuju da rečeni raspon ne odražava nužno kronološku, već kanonsku povijest, pošto rabinska tradicija smješta Knjigu Ljetopisa na kraj posljednjeg, trećeg dijela tripartitnoga hebrejskog kanona. ${ }^{35}$ Raspon od Abela do Zaharije odgovara, dakle, rasponu kanonskih knjiga hebrejskog kanona od Postanka do Ljetopisa. Beckwith (1986, 211-22) stoga koristi taj tekst i Matejevo evanđelje 23,35 kako bi ustvrdio da je takav zatvoreni hebrejski kanon postojao već u 1. stoljeću te da je ekvivalentan odgovarajućem kanonskom rasporedu koji se navodi u Talmudu (b. B. Bat 14b-15a).

Dok mnogi slijede ovo tumačenje bez puno razmišljanja, tumačenje samoga kanonskog raspona ipak podliježe raspravi. ${ }^{36}$ H. G. L. Peels (2001) dopušta

\section{The Jewish War, IV.334-344.}

Chapman $(1912,402)$ tvrdi: “da je zaista bio kršćanski mučenik, bio bi znatno popularniji."

Kronološki gledano, mučeništvo koje se kasnije desilo u Svetom pismu opisano je u Jeremiji 26,20-23.

Za kritički osvrt na rad Beckwitha, vidjeti R. L. Harris (1990, 75-84), koji problem razmatra iz Beckwithove pozicije da je Knjiga Ljetopisa predstavljala završetak kanona, a koji se općenito slaže s postavkom tripartitnog kanona. Ne smatra da je identitet Zaharije kao Jojadina sina vrlo uvjerljiv, no umjesto toga ne pruža nikakvu uvjerljivu alternativu. 
mogućnost da je ovaj Zaharija zaista Jojadin sin, ali protivi se tvrdnji Beckwitha i drugih da raspon mučenika predstavlja kanonski raspon. Tvrdi da kanonski raspon mučenika ne odgovara neposrednom kontekstu zato što bi onda „ovaj naraštaj" nosio odgovornost za krv samo tih mučenika. Peels stoga smatra da navedeni raspon treba objasniti „prije svega u smislu kvalifikacija“, što uključuje mučenike čija smrt vapi za osvetom. Prema Peelsu, ubojstva Abela i Zaharije predstavljaju jedina dva slučaja koja odgovaraju traženim kriterijima - nasilno ubojstvo nevine osobe koje je povezano s činjenicom da je ta osoba posvećena Bogu i stoga zahtijeva osvetu (Peels 2001, 598). On zaključuje da se „tekst odnosi na dvije osobe koje u rasponu od nekoliko stoljeća oslikavaju cjelokupnu tragediju ubijanja Božjih slugu“" (Peels 2001, 599). Nadalje, Peels izjavljuje da:

Isusova namjera nije toliko da označi početnu i završnu točku linearnoga kanonskog vremena, koliko mu je namjera dodirnuti dva duboko bolna događaja iste pojave koja je prisutna već stoljećima i koja se nastavlja događati u sadašnje vrijeme (Peels 2001, 599).

Dakle, prema Peelsu, ni Matejevo evanđeljet 23,35 ni Lukino 11,50 ne pretpostavljaju kanonski raspored. Iako Peels pruža konceptualno uvjerljivu zamisao kanonskog raspona, ipak propušta posvetiti dostojnu pažnju jasnoj sintaktičkoj

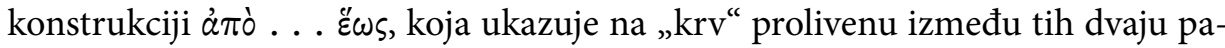
rametara. Zapravo, Peels odmah uvodi u svoj argument taj „vremenski aspekt“, dodajući samo to da fraza „izražava puno više od toga“ (Peels 2001, 597).

Peelsova ranija zamjerka da će osvećeni mučenici biti ograničeni samo na kanonske mučenike zapravo propušta uočiti širu svrhu ovih redaka da Isus te proroci i apostoli, koje on šalje, predstavljaju vrhunac rekapitulacije povijesti Svetog pisma. Tvrdnja da će „ovaj naraštaj“ biti odgovoran za svu krv, ne može doslovce značiti da je naraštaj Isusova vremena isključivo odgovoran za ono što su činili svi prethodni naraštaji, stoga što je jasno da je božanski sud djelovao u prošlosti, kao što se to jasno ističe u 2. Ljetopisa 36,19-20.

Tekst više izražava tipologiju vrhunca osude. Baš kao što Isus i njegovi poslanici tipološki ispunjavaju ulogu prototipskih kanonskih proroka, koji su bili proganjani i ubijani tijekom biblijske povijesti, sadašnji naraštaj pisara-učenjaka koji će progoniti Isusa i njegove poslanike tipološki ispunjavaju ulogu prototipskih progonitelja. No kako se ti događaji sada zbivaju u vrijeme eshatološkog dolaska Mesije, predstavljaju vrhunac rekapitulacije prijašnjih kanonskih događaja. Tako se izraz „od Abela do Zaharije“ najbolje može razumjeti kao postavljanje kanonskih parametara za biblijske prototipove mučenika, za koje Isus i njegovi poslanici donose eshatološko, tipološko ispunjenje.

Međutim, Peelsov oprez glede Beckwithova korištenja odlomka sa svrhom da dokaže postojanje zaključanoga starozavjetnog kanona, još je uvijek opravdan. „Kanonski“ raspon prototipskih mučenika ne može neupitno dokazati da je takav 
kanonski raspored bio prihvaćen u svim misaonim strujanjima judaizma toga vremena, niti da je zbirka nužno bila zaključana na neki formalni način. Sasvim je moguće da je u to vrijeme postojalo nekoliko mogućih rasporeda. ${ }^{37}$ No to ne isključuje mogućnost da je postojala kanonska tradicija Postanak - Ljetopisi koja je funkcionirala u židovskim i ranokršćanskim krugovima. ${ }^{38}$ Kao što se prethodno ustvrdilo, ima dovoljno dokaza u samome Starom zavjetu i judaizmu iz razdoblja drugoga hrama koji sugeriraju da je postojao tripartitni kanonski okvir. Trostruki

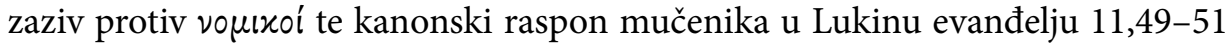
podržavaju dokaz postojanja takvoga kanonskog okvira.

\section{Zaključci i njihove posljedice}

Već sam pokazao da četiri elementa u Lukinu evanđelju 11,45-51 doprinose inkorporiranju Isusa i njegovih poslanika unutar tripartitnoga kanonskog okvira.

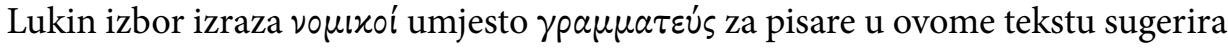
retoričku taktiku naglašavanja uloge pisara-učenjaka u tumačenju svetih spisa i općeg aludiranja na Sveto pismo u cijelosti. Nadalje, strukturiranje triju zaziva protiv voulxoĺ, koje tematski korespondira s tripartitnim kanonskim okvirom, podržava ovu široku aluziju na Sveto pismo u cijelosti.

Treće, u središnjem zazivu pokazalo se da je govor objave „mudrosti Božje“ utemeljen na obrascu poslanje - otpadništvo - osuda iz 2. Ljetopisa 24 i 36, koji je sada obnovljen i rekapituliran u autoritativnoj osobi Isusa, koji sam šalje apostole i proroke. Ova rekapitulacija služi za inkorporiranje Isusa i njegovih poslanika unutar tripartitnog okvira na koji se jasno aludira. Konačno, kanonski raspon mučenika od Abela do Zaharije potvrđuje ovu tipološku rekapitulaciju na način da su očekivana buduća mučeništva te progoni Isusa i njegovih apostola tijekom ranoga kršćanskog pokreta, kao i osuda sadašnjeg naraštaja pisara-učenjaka i njihovih saveznika, tipološki povezani s povijesnim progonima biblijskih proroka od strane judejskih vođa iz 2. Ljetopisa 24 i 36.

Lukin poseban način prikazivanja ove epizode služi, dakle, autoru da progovori o progonima i ubijanju Isusa te njegovih poslanika, kao vrhuncu kontinuiteta kanonske prošlosti. Tako ovaj tekst pokazuje da je ukupni Lukin opus, njegovo evanđelje i Djela, pisani nastavak tripartitne tradicije objave i dio kanonskog okvira starozavjetnih spisa.

37 Neki hebrejski rukopisi smještaju Knjigu Ljetopisa na početak 3. dijela kanona (Braun 1986, xix).

38 Alternativno, knjiga Ljetopisa mogla se razumjeti kao reprezentativna knjiga 3. dijela kanona i još uvijek poslužiti u istu svrhu. 


\section{Bibliografija}

Allison, Dale C. 2000. The Intertextual Jesus: Scripture in Q. Harrisburg, PA: Trinity Press International.

Balla, Peter. 2002. "Evidence for an Early Christian Canon (Second and Third Century)." In The Canon Debate, edited by Lee Martin McDonald and James A. Sanders, 372-85. Peabody, MA: Hendrickson.

Beckwith, Roger. 1986. The Old Testament Canon of the New Testament Church and Its Background in Early Judaism. Grand Rapids: Eerdmans.

Bickerman, Elias J. 1945. “The Date of Fourth Maccabees." In Louis Ginzberg Jubilee Volume on the Occasion of His Seventieth Birthday. New York: The American Academy for Jewish Research.

Bock, Darrell L. 1996. Luke Volume 2: 9.51-24.53. Vol. 2. 2 vols. Baker Exegetical Commentary on the New Testament 3B. Grand Rapids: Baker.

Braun, Roddy. 1986. 1 Chronicles. Word Biblical Commentary 14. Waco, TX: Word.

Chapman, John. 1912. "Zacharias, Slain between the Temple and the Altar." The Journal of Theological Studies os-XIII (51): 398-410.

Chapman, Stephen B. 2000. The Law and the Prophets: A Study in Old Testament Canon Formation. Forschungen zum Alten Testament 27. Tübingen: Mohr Siebeck.

Davies, W. D., and D. C. Allison. 1988-1997. A Critical and Exegetical Commentary on the Gospel According to Saint Matthew. 3 vols. ICC. Edinburgh: T\&T Clark.

Dempster, Stephen G. 1997a. "An 'Extraordinary Fact' : Torah and Temple and the Contours of the Hebrew Canon, Part 1." Tyndale Bulletin 48 (1): 23-56.

Dempster, Stephen G. 1997b. "An 'Extraordinary Fact': Torah and Temple and the Contours of the Hebrew Canon : Part 2." Tyndale Bulletin 48 (2): 191218.

Dempster, Stephen G. 2008. “Torah, Torah, Torah.” In Exploring the Origins of the Bible: Canon Formation in Historical, Literary, and Theological Perspective, edited by Craig A. Evans and Emanuel Tov, 87-127. Acadia Studies in Bible and Theology. Grand Rapids: Baker Academic.

Denova, Rebecca I. 1997. The Things Accomplished Among Us: Prophetic Tradition in the Structural Pattern in Luke-Acts. Library of New Testament Studies 141. Sheffield, UK: Sheffield Academic Press.

deSilva, David A. 1998. 4 Maccabees. Guides to Apocrypha and Pseudepigrapha. 
Sheffield England: Sheffield Academic Press.

deSilva, David A. 2006. 4 Maccabees: Introduction and Commentary on the Greek Text in Codex Sinaiticus. Septuagint Commentary Series. Leiden: Brill.

Ellis, E. Earle. 1963. “Luke 11:49-51: An Oracle of a Christian Prophet?” Expository Times 74 (5): $157-58$.

Fitzmyer, Joseph A. 1985. The Gospel According to Luke X-XXIV: Introduction, Translation, and Notes. Vol. 2. 2 vols. AB 28a. Garden City N.Y.: Doubleday.

Gowler, David B. 1994. "Hospitality and Characterization in Luke 11:37-54: A Socio-Narratological Approach.” Semeia 64: 213-51.

Green, Joel B. 1997. The Gospel of Luke. New International Commentary on the New Testament. Grand Rapids: Eerdmans.

Harris, R. Laird. 1990. "Chronicles and the Canon in New Testament Times." Journal of the Evangelical Theological Society 33 (1): 75-84.

Hayward, Robert. 1985. "Some Notes on Scribes and Priests in the Targum of the Prophets." Journal of Jewish Studies 36: 210-21.

Kruger, Michael J. 2012. Canon Revisited: Establishing the Origins and Authority of the New Testament Books. Wheaton, IL: Crossway.

Kruger, Michael J. 2013. The Question of Canon: Challenging the Status Quo in the New Testament Debate. Downer's Grove, IL: IVP Academic.

Marshall, I. Howard. 1978. The Gospel of Luke: A Commentary on the Greek Text. New International Greek Testament Commentary. Grand Rapids: Eerdmans.

McDonald, Lee Martin, and James A. Sanders. 2002. "Introduction." In The Canon Debate, edited by Lee Martin McDonald and James A. Sanders, 3-17. Peabody, MA: Hendrickson.

Nolland, John. 1993. Luke 9:21-18:34. WBC 35b. Dallas: Word Books.

Peels, H. G. L. 2001. “The Blood 'from Abel to Zechariah' (Matthew 23,35; Luke 11,50f.) and the Canon of the Old Testament." Zeitschrift für die alttestamentliche Wissenschaft 113 (4): 583-601.

Redditt, Paul L. 1983. "The Concept of Nomos in Fourth Maccabees." Catholic Biblical Quarterly 45: 249-70.

Saldarini, Anthony J. 1988. Pharisees, Scribes and Sadducees in Palestinian Society: A Sociological Approach. Wilmington, DE: Michael Glazier.

Sanders, Jack. 1987. The Jews in Luke-Acts. Philadelphia: Fortress.

Schams, Christine. 1998. Jewish Scribes in the Second-Temple Period. Journal for the Study of the Old Testament: Supplemental Series 291. Sheffield: Sheffi- 
eld Academic Press.

Seitz, Christopher R. 2009. The Goodly Fellowship of the Prophets: The Achievement of Association in Canon Formation. Acadia Studies in Bible and Theology. Grand Rapids: Baker Academic.

Smith, Dennis. 1987. "Table Fellowship as a Literary Motif in the Gospel of Luke." Journal of Biblical Literature 106 (4): 613-38.

Smith, D. Moody. 2000. "When Did the Gospels Become Scripture?" Journal of Biblical Literature 119: 3-20.

Steele, E. Springs. 1984. "Luke 11:37-54: A Modified Hellenistic Symposium?" Journal of Biblical Literature 103 (3): 379-94.

Suggs, M. Jack. 1970. Wisdom, Christology, and Law in Matthew's Gospel. Cambridge: Harvard University Press.

Sundberg, Albert. 1964. The Old Testament of the Early Church. Cambridge: Harvard University Press.

Thellman, Gregory S. 2013. “Scribes.” Edited by Joel B. Green, Jeannine K. Brown, and Nicholas Perrin. Dictionary of Jesus and the Gospels. Downer's Grove, IL: IVP Academic.

Thellman, Gregory S. 2016. "Revealing the Past and Envisioning the Future: Matthew's Apocalyptic Frame.” Ph.D. diss., Wheaton, IL: Wheaton College.

Prevela s engleskog Dalia Matijević

Gregory S. Thellman

\title{
The Incorporation of Jesus and His Emissaries in a Tripartite Canonical Framework (Luke 11:45-53)
}

\begin{abstract}
This composition critical exegetical study examines Luke's distinctive presentation of Jesus' woes against the scribal scholars in Luke 11:45-51. Four elements of Luke's presentation are identified which contribute to the inclusion of Jesus and his emissaries within a distinctly tripartite canonical framework. Luke's peculiar use of the Greek term voulxós is shown to be employed as a rhetorical marker to emphasize the scripture interpreting role of the scribal scholars and to provide a broad allusion to scripture overall. The correspondence of the three woes against
\end{abstract}


the vouıxoi to the tripartite Hebrew canon is demonstrated as further evidence for this allusion to scripture and a three-fold revelatory tradition. Two elements within the second woe, the saying of the "Wisdom of God," and the range of past martyrs, are then discussed and found to have intertextual links with 2 Chronicles 24 and 36, suggesting the present passage is a typological recapitulation of past persecution and martyrdom, as well as judgment. The article concludes that these distinctive elements show that Luke typologically incorporates Jesus and his emissaries within a tripartite revelatory tradition and canonical framework, and that by further implication, Luke's written testimony (Luke-Acts) to the persecution and killing of Jesus and his sent ones, contributes to the self presentation of this written testimony as a climactic continuation of the OT scriptures. 